\title{
Starzeć się pięknie, czyli jak? Słów kilka o estetyzacji starzejącego się ciała seniora
}

\section{Wstęp}

Naturalnym przymiotem człowieka jest jego wrażliwość na piękno. Zachwyca go zjawiskowość przyrody, obrazów, utworów muzycznych, literackich czy też piękno fizyczne i/lub duchowe innych osób. Na temat piękna zapisano wiele tomów. Systematyzację wiedzy w tym zakresie zapoczątkował Aleksander Baumgarten, który w 1735 r. wprowadził do dyskursu naukowego termin aesthetics, kładąc podwaliny pod nową dyscyplinę filozoficzną, której celem było ustalenie ogólnych zasad piękna oraz przeżyć z nim związanych¹.

Słowo „estetyka” pochodzi od greckiego aisthesis i posiada dwa znaczenia. Po pierwsze rozumiane jest jako postrzeganie, odnoszące się do pierwotnych jakości zmysłowych, tj. kolory, dźwięki, smaki czy zapachy, służących ich rozpoznaniu. Po drugie aisthesis to odczucie, czyli perspektywa emocjonalna, odnosząca nas do tego, co odbieramy jako przyjemne lub budzące niezadowolenie $^{2}$. A. Baumgarten definiował estetykę jako szlachetną dziedzinę poznania zmysłowego, jako dopełnienie logiki, stanowiące obok poznania mierzalnego i naukowego, „podejście intuicyjne, niedające się zdefiniować, a jednak dosko-

* Dr Emilia Kramkowska - Zakład Socjologii Wiedzy i Edukacji; Instytut Socjologii, Uniwersytet w Białymstoku, e-mail: e.kramkowska@uwb.edu.pl, ORCID: 0000-0002-6420-7014.

1 W. Welsch, Estetyka poza estetyka. O nowa postać estetyki, red. K. Wilkoszewska, tłum. K. Guczalska, Towarzystwo Autorów i Wydawców Prac Naukowych Universitas, Kraków 2005, s. 42.

2 W. Welsch, Est/etyka. Etyczne implikacje i następstwa estetyki, tłum. i oprac. D. Kolasa, T. Siwiec, w: Między etykq a estetyką. Rozważania nad problemem estetyzacji, red. K. Kaśkiewicz, R. Michalski, T. Siwiec, Wydawnictwo Naukowe UMK, Toruń 2017, s. 30. 
nale spełniające nasze oczekiwania w pewnych dziedzinach życia”3. Podobne przekonanie wyrażał jeden z polskich klasyków teorii estetyki Władysław Tatarkiewicz. Zwracając uwagę na właściwe estetyce postrzeganie i odczucie, tłumaczył, czym jest przeżycie estetyczne, podkreślając jego znaczenie dla ludzkiej egzystencji. Filozof klasyfikuje je w trzech wymiarach: przeżycia estetyczne w wąskim znaczeniu - odnoszące się do wyglądu przedmiotu, dalej - przeżycia poetyckie powiązane $\mathrm{z}$ komponentem emocjonalnym i po trzecie - przeżycia literackie - z dominującą rolą czynnika intelektualnego ${ }^{4}$. Nietrudno więc zauważyć, że naukowy dyskurs prowadzony w ramach estetyki - najmłodszej dziedziny filozofii - obrał kierunek zarówno w stronę piękna, jak i sztuki. Pozwoliło to na wypracowanie różnych interpretacji zjawisk estetycznych. I tak np. w podejściu rodzimego estetyka Stanisława Ossowskiego zagadnienia estetyczne ujmowane są z socjologiczno-psychologicznego punktu widzenia. Autor zwracał uwagę na przeżycia estetyczne odbiorcy danego dzieła artystycznego, choć bardziej interesował go wymiar społeczny - dzieło sztuki jako węzeł stosunków społecznych, jako dzieło dla kogoś i dzięki komuś. Jego rozprawa habilitacyjna U podstaw estetyki to klasyka gatunku zarówno na gruncie estetyki, jak i socjologii sztuki ${ }^{5}$. Z kolei estetyka fenomenologiczna Romana Ingardena to zwrócenie uwagi na intencjonalność dzieł sztuki, które mogą zaistnieć dzięki przedmiotom materialnym i aktom twórczym człowieka. Filozof wskazując na ważność jednostki - twórcy dzieła, jak i kultury ujawniającej lub ucieleśniającej wartości dobra i piękna, przypomina, że człowiek może doznać pełni szczęścia przede wszystkim obcując z wartościami estetycznymi i moralnymi, będącymi najwyższym rodzajem wartości ${ }^{6}$.

Na kartach współczesnej literatury z zakresu estetyki odnajdujemy dwa główne obszary opisywanych zagadnień. Pierwszy zbiór opracowań dotyczy relacji między estetyką a etyką, ukazując m.in. etyczne następstwa zmian dokonujących się na gruncie myślenia estetycznego ${ }^{7}$. Polski estetyk Henryk Elzenberg, łącząc myśl estetyczną z refleksją aksjologiczną, podkreślał, że to właśnie wartości, fundamentalna kategoria w rozważaniach estetycznych, stanowią podstawę

${ }^{3}$ K. Kaśkiewicz, R. Michalski, Estetyzacja moralności - dylematy współczesnego człowieka, w: Między etykq a estetyką..., s. 7.

4 W. Tatarkiewicz, Dzieje sześciu pojęć. Sztuka, piękno, forma, twórczość, odtwórczość, przeżycie estetyczne, PWN, Warszawa 1982, s. 361-392.

S. Ossowski, U podstaw estetyki, PWN, Warszawa 1966.

${ }^{6}$ R. Ingarden, Wykłady i dyskusje z estetyki, wybór i oprac. A. Szczepańska, wstęp W. Stróżewski, PWN, Warszawa 1981, s. 165-184.

7 A. Kersten, When Craving Goodness Becomes Bad. A Critical Conception of Ethics and Aesthetics in Organizations, „Culture and Organization” 2008, t. 14, nr 2, s. 187-202; M. Jimenez, Etyka i estetyka w XXI wieku, tłum. E.I. Nowak, „Sztuka i Filozofia” 2012, t. 41, s. 15-23; E. Brady, Aesthetic Value, Ethics and Climate Change, „Environmental Values” 2014, t. 23, nr 5, s. 551-570; O. Naukkarinen, Everyday Aesthetic Practices, Ethics and Tact, „Aisthesis” 2014, t. 7, nr 1, s. 23-44. 
aktywności i zmagań moralnych człowieka, a ich urzeczywistnianie powinno być jego naczelnym celem i powinnością. Filozof wiele miejsca poświęcił wyjaśnieniu własnej, dość szerokiej interpretacji piękna, które utożsamiał z dobrem. Piękno nie posiada wyłącznie natury zmysłowej, gdyż - zdaniem H. Elzenberga - przysługuje również czynom, przyrodzie czy epokom. Brak precyzyjnych granic między tym, co jest piękne, a tym, co piękne nie jest, wynika $\mathrm{z}$ faktu ich wewnętrznego rodowodu, tzn. decyduje o tym wnętrze człowieka, jego odczucia, uosobienie czy doświadczenia. Pięknym nazywamy to, co oceniamy jako wartościowe. Rozpoznanie i interioryzacja właściwego porządku rzeczy usposabia człowieka do przykładnego życia w cnocie, które przecież postrzegane jest jako dobre i piękne ${ }^{8}$. Pomóc w tym może wychowanie estetyczne, opisywane m.in. przez Stefana Szumana. Autor tłumaczy, że „dzieła sztuki, właściwie odebrane, stają się istotnym czynnikiem pełnego kształtowania osobowości, stanowiąc - obok źródła doznań (uczuć) stricte estetycznych - także istotny czynnik moralnego, społecznego i światopoglądowego wychowania ludzi”".

Drugą grupę dostępnych opracowań stanowią publikacje opisujące różne wymiary estetyzacji rzeczywistości, czyli jej upiększania, co wydaje się być podejściem odbiegającym od sposobu rozumienia zagadnień estetycznych zaproponowanego przez A. Baumgartena. Niemiecki socjolog i kulturoznawca Andreas Reckwitz uważa, że pojęcie estetyzacji pod koniec XX w. zostało zreaktywowane, a przy tym poszerzone i przeformułowane, często dystansując się od idealistycznego rozumienia estetyki ${ }^{10}$. Kontekst rozważań podejmowanych w niniejszym tekście wymaga szerszego omówienia zagadnienia estetyzacji.

\section{Pojęcie estetyzacji i jej wymiary - wyjaśnienia teoretyczne}

Najogólniej rzecz ujmując, estetyzacja to proces, w którym coś „pozaestetycznego zostaje uczynione czymś estetycznym bądź jest pojmowane jako coś estetycznego"'ll. Trend ten można dziś zaobserwować we wszystkich dziedzinach życia. Uta Kösser zauważa podobieństwo pojęcia „estetyzacja” z innymi terminami z sufiksem -zacja (np. ekonomizacja), które opisując określony stan rzeczy, podporządkowują go prawom rządzącym w danej przestrzeni. Ma to swoje praktyczne zastosowanie, tzn. estetyzacja może być procesem realizującym

8 H. Elzenberg, Pisma etyczne, oprac. i wstęp L. Hostyński, Wydawnictwo Uniwersytetu Marii Curie-Skłodowskiej, Lublin 1999, s. 7-20.

9 S. Szuman, O sztuce i wychowaniu estetycznym, Państwowe Zakłady Wydawnictw Szkolnych, Warszawa 1969, s. 100-101.

10 A. Reckwitz, Odkrycie kreatywności. O procesie społecznej estetyzacji, tłum. K. Kończal, Z. Sucharska, Narodowe Centrum Kultury, Warszawa 2017, s. 30-31.

${ }^{11}$ W. Welsch, Estetyka poza estetyką. O nowa postać estetyki..., s. 41. 
pewne interesy, więc instrumentalizującym to, co estetyczne, np. estetyzacja towarów służy interesom ekonomicznym. „Estetyzacja oznacza, że strategie estetyczne będą stosowane na takich obszarach, które pierwotnie podlegały kształtowaniu innemu niźli estetyczne; że strategie estetyczne stosuje się po to, aby posłużyły pozaestetycznym, często materialnym celom"12. W rezultacie uwaga odbiorcy skupia się na tym, co piękne versus brzydkie, a prawdziwość przekazu może zniknąć z pola widzenia. Zdaniem Wolfganga Welscha działania na rzecz globalizacji estetyczności są podejmowane przez głosicieli tychże idei, w imię czynienia świata lepszym ${ }^{13}$. Czy tak się faktycznie dzieje?

Fenomen estetyzacji posiada wiele wymiarów. W literaturze przedmiotu czytamy o estetyzacji powierzchownej i głębokiej oraz o społecznym i indywidualnym jej wymiarze.

Społeczny wymiar procesów estetyzacji to kształtowanie się nowej wersji rzeczywistości społecznej, zdominowanej przez rynkowe czy medialne mechanizmy. Nazywa się ją estetyczną społecznością ${ }^{14}$. Maria Gołaszewska społeczny wymiar estetyzacji definiuje jako „strukturowanie rzeczywistości, jej kształtowanie i ujmowanie pojęciowe w struktury zaczerpnięte ze sztuki, dzięki czemu uzyskuje ona nowy ład, nowe wartości, by nie powiedzieć: piękno"15. Zdaniem badaczki punktem wyjścia tegoż procesu jest przyjęcie wobec rzeczywistości „postawy estetycznej”, tzn. postawy twórczej, zakładającej odkrywanie wartości i nadawanie ich przedmiotom oraz zjawiskom, docieranie do struktur głębokich, podstawowych mechanizmów rządzących światem człowieka ${ }^{16}$. M. Gołaszewska włącza w estetyzację rzeczywistości zdarzenia życiowe, wszelkie zjawiska i przedmioty czy świat przyrody. Jasne jest zatem, że upodabnianie zwyczajności do form artystycznych czy paraartystycznych byłoby niemożliwe bez człowieka - kreatora tychże przeobrażeń. Nazwano go homo aestheticus.

Człowiek estetyczny jest zmysłowy, hedonistyczny, wykształcony i ma wyborny smak. Zdaniem M. Gołaszewskiej wartości estetyczne są jedynym z kluczowych punktów odniesienia człowieka wobec otaczającej go rzeczywistości, „są osadzone głęboko w samym rdzeniu naszych sposobów widzenia świata, modyfikując na różne sposoby nasze doznawanie"17. Wydaje się być to szczególnie zauważalne w postawie współczesnego człowieka wobec samego siebie, a konkretnie wobec własnego wyglądu czy cielesności. Jednostkowy wymiar procesów estetyzacji rzeczywistości jest dziś niezwykle silny, a zdaniem W. Wel-

12 U. Kösser, Piękne, dobre i prawdziwe? O estetyzacji i anestetyzacji historii, w: Między etyką a estetyka..., s. 266.

13 W. Welsch, Estetyka poza estetyką. O nowa postać estetyki..., s. 121.

14 A. Reckwitz, Odkrycie kreatywności. O procesie społecznej estetyzacji..., s. 319.

15 M. Gołaszewska, Estetyka rzeczywistości, Instytut Wydawniczy PAX, Warszawa 1984, s. 71.

16 Tamże, s. 71-75.

17 Tamże, s. 163. 
scha „W sferze indywiduum współczesna estetyzacja zdaje się osiągać wręcz swoje spełnienie. Wszędzie dokonuje się styling ciała, psychiki i ducha - w ogóle wszystkiego cokolwiek mogą mieć (bądź zafundować sobie) nowi, piękni ludzie, którzy uprawiają estetyczną perfekcjonizację ciała"18. W kulturze ponowoczesnej ciało zajmuje miejsce centralne, a naukowa refleksja w tym zakresie wykreowała nowe subdyscypliny, jak np. socjologię czy antropologię ciała, badające ciało nie tylko jako materialny substrat egzystencji, lecz także przedmiot i podmiot różnorodnych społecznych dyskursów i praktyk ${ }^{19}$. Zauważamy to w odniesieniu do estetyzacji cielesności, przejawiającej się na dwa sposoby.

Pierwszym jest budowanie wizerunku, czyli refleksyjne monitorowanie i zarządzanie ciałem, dbałość o wygląd zewnętrzny, gesty czy strój, co może informować otoczenie o społecznym statusie jednostki, jak też jej stylu życia, osobowości, upodobaniach i pasjach. Takie zarządzanie cielesnością daje możliwość autokreacji i „stwarzania siebie” w drodze eksperymentowania i wypróbowywania różnych tożsamości czy „projektów ciała”20.

Drugim miernikiem jest konsumowanie wrażeń. „Ciało kształtuje się w procesie konsumowania i bycia konsumowanym. Staje się źródłem przeżycia, a więc obietnicą zaspokojenia. (...) Ludzie zwykle konsumują to, co zobaczą i czego pozazdroszczą innym" ${ }^{21}$. Zachowania te przejawiają się też w tym, co W. Welsch nazywa estetyzacją powierzchowną i głęboką.

Estetyzacja powierzchowna „oznacza tyle co upiększanie, czyli wyposażanie rzeczywistości w elementy estetyczne"22, dla wywołania przeżycia będącego efektem dostrzeżenia czegoś pięknego. Powierzchowny poziom estetyzacji przybiera postać upiększania przestrzeni miejskiej, nadawania szykownego wyglądu centrom handlowym, biurom czy restauracjom. Wydaje się, że prywatna przestrzeń ludzka, a dokładniej ciało człowieka, jego wygląd (powierzchowność) jest płaszczyzną, na której widoczne są efekty oddziaływania estetycznych strategii. „W powierzchownej estetyzacji - zdaniem W. Welscha - dominuje najbardziej płytka wartość estetyczna: przyjemność, rozrywka, używanie bez konsekwencji

18 W. Welsch, Estetyka poza estetyką. O nowa postać estetyki..., s. 38.

19 N. Elias, Przemiany obyczajów w cywilizacji Zachodu, tłum. T. Zabłudowski, PIW, Warszawa 1980; M. Foucault, Body/ Power, w: Michel Foucault. Power/Knowledge. Selected Interviews and Other Writings 1972-1977, red. C. Gordon, Harvester, Brighton 1980; B. Turner, The Body and Society, Basil Blackwell, Oxford-New York 1984; M. Mauss, Socjologia i antropologia, tłum. M. Król, K. Pomian, J. Szacki, Wydawnictwo KR, Warszawa 2001; P. Bourdieu, Męska dominacja, tłum. L. Kopciewicz, Oficyna Naukowa, Warszawa 2004; H. Jakubowska, Socjologia ciała, Wydawnictwo Naukowe Uniwersytetu im. A. Mickiewicza, Poznań 2009; Ch. Shilling, Socjologia ciała, Wydawnictwo Naukowe PWN, Warszawa 2010.

20 M. Flis, Dynamika ciała w kulturze wizerunku, „Horyzonty Wychowania” 2008, t. 7, nr 14, s. 108.

${ }_{21}$ Tamże, s. 108-109.

22 W. Welsch, Estetyka poza estetyką. O nowa postać estetyki..., s. 33. 
(...), co w ostatnich latach stało się ideą przewodnią kultury"23. Nierzadko bardziej zwracamy uwagę na estetyczną aurę produktu, na towarzyszące mu przeżycie i zachwyt niż na sam produkt czy jego użyteczność. Estetyzacja powierzchowna ma też swoje zakorzenienie w estetyzacji głębokiej.

Estetyzacja głęboka „dotyczy fundamentalnych struktur rzeczywistości jako takiej: rzeczywistości materialnej (...), rzeczywistości społecznej (...) czy rzeczywistości podmiotowej"24. Oznacza ona, że estetyczność staje się priorytetem, tzn. „bazą”. Urealnia się wówczas, gdy współczesny człowiek poszukuje nowych przeżyć estetycznych i piękna, czy to w odniesieniu do materiałów, z których są wykonane kupowane przez niego produkty, czy to w płaszczyźnie społecznej zapośredniczonej przez media estetycznie modelujące swój przekaz. „Estetyzacja głęboka dotyka samego człowieka, modyfikując odpowiednio do uwarunkowań estetyzacyjnych poziom jego moralności, świadomości i myślenia, czy jego lifestyle”25. O uwarunkowaniach tego procesu tak pisze Agnieszka Jęczeń: „Nie można wykluczyć, iż przyczyną estetyzacji jest panujące wśród ludzi odczucie powszechnego nienasycenia nowością, formą, powszechny niedosyt wrażeń, uczuć, doznań zmysłowych i wartości (...) Istotą estetyzacji jako procesu jest krystalizacja nowej filozofii życia"26.

Otwartość człowieka na wciąż nowe doznania zmysłowe, jak też ujmowanie ludzkiego ciała w kontekście wartości estetycznych nie jest niczym nowym lub zaskakującym. Wygląd ciała człowieka, jego atrakcyjność, sylwetka itp. od zawsze stanowiły jedną z kluczowych cech, w oparciu o którą ludzie postrzegali innych, dobierali się w pary itd. Jeśli jednak przypomnimy, że estetyzacja to nadawanie pozaestetycznym obiektom wymiaru piękna i atrakcyjności, to w nieco innym świetle jawi się wyrażenie „estetyzacja starzejącego się ciała seniora”27.

Postępujący proces starzenia się ludności świata jest faktem. W 2020 r. światowa populacja osób w wieku 60 lat i więcej liczyła ok. 1 miliarda, a według prognoz do 2050 r. podwoi się. Zainicjowana w latach pięćdziesiątych XX w. przez Edwarda Cowdry dziedzina badań o charakterze wielo- i interdyscyplinarnym gerontologia - miała zbadać podstawowe mechanizmy związane ze starzeniem się człowieka, a także przyczyny ubóstwa i chorób osób w podeszłym wieku. E. Cowdry wierzył, że patrząc na proces starzenia się przez pryzmat biologiczny

23 Tamże, s. 34.

24 Tamże, s. 40-41.

25 W. Welsch, Est/etyka. Etyczne implikacje i nastepstwa estetyki..., s. 50.

26 A. Jęczeń, Estetyzacja w kulturze współczesnej jako poszukiwanie sensu, „Kultura - Media Teologia" 2012, nr 8, s. 9.

27 Według biologów procesy starcze rozpoczynają się w trzeciej dekadzie życia człowieka, ale ich skutki zwykle dostrzegamy ok. 50. roku życia. Dlatego uznaję za zasadne pisanie o starzejącym się ciele seniora, by zwrócić uwagę Czytelnika na fakt, iż przedmiotem moich rozważań jest konkretny etap życia, czyli starość, w którym człowiek najbardziej zdaje się doświadczać skutków zmieniającego się ciała. 
i moralny, będzie możliwa zmiana postrzegania rosnącej liczby osób starszych ze społecznego problemu w społeczne dobro ${ }^{28}$. Tymczasem puentą publicznych dyskusji dotyczących konsekwencji postępujących procesów starzenia się ludności jest częste stwierdzenie, iż seniorzy generują liczne wyzwania, m.in. dla systemów emerytalnych poszczególnych państw, systemu ochrony zdrowia czy pomocy społecznej. Nierzadko słyszy się o zachowaniach dyskryminujących osoby starsze czy też o ich samodyskryminacji bądź samowykluczeniu. Wiele procesów społecznych dzieje się też niejako bezwiednie, ale ich wpływ na seniorów jest bezsprzeczny.

$\mathrm{W}$ przedkładanym tekście będzie nas interesować postępująca estetyzacja rzeczywistości, analizowana w kontekście ogólnoświatowych procesów starzenia się ludności. Dokładniej rzecz ujmując, artykuł dotyczy zagadnienia estetyzacji starzejącego się ciała seniora, analizowanego w oparciu o wyniki badań prowadzonych wśród osób starszych.

\section{Metodologia badań}

Podstawą analiz prowadzonych w niniejszej pracy są badania porównawcze wykonane wśród seniorów pochodzących z trzech państw: Polski, Bułgarii i Portugalii. Uzasadnienie wyboru tych krajów jako studium przypadku opiera się, podobnie jak ogólna filozofia leżąca u podstaw podejścia porównawczego, na kombinacji podobieństw i różnic ${ }^{29}$. Podobieństwa są wyraźne - wszystkie kraje charakteryzują się zbliżonym, powojennym tłem historycznym, przywiązaniem do tradycji czy wartości kultury chrześcijańskiej ${ }^{30}$. Wśród licznych różnic będzie nas interesować odmienne doświadczanie skutków postępujących procesów starzenia się społeczeństwa.

Z najnowszej analizy GUS wynika, że w końcu 2019 r. liczba ludności Polski wynosiła 38,2 mln, z czego 9,7 mln to osoby w wieku 60 lat i więcej, stanowiące $25,3 \%$ ogółu ludności. Relatywnie najmłodsza grupa (60-64 lata) miała w 2019 r. największy udział $(28,4 \%)$ w strukturze wieku osób starszych.

28 T. Mann, Old Cells, Aging Bodies, and New Money: Scientific Solutions to the Problem of Old Age in the United States, 1945-1955, „Journal of World History” 2014, t. 24, nr 4, s. 798.

${ }^{29}$ K. Bargłowski, Where, What and Whom to Study? Principles, Guidelines and Empirical Examples of Case Selection and Sampling in Research, w: Qualitative Research in European Migration Studies, red. R. Zapata-Barrero, E. Yalaz, Springer, Switzerland 2018, s. 151- 168.

30 S. Naoumova, Ethnicity and Expectations Concerning Family Law and Family Values in Bulgaria, w: Family Law and Family Values, red. M. Mavis, Hart Publishing, London 2003, s. 277-294; A. Rychłowska-Niesporek, Transformation of family in Poland, w: Modern Social and Educational Challenges and Phenomena: Polish and Macedonian Perspectives, red. M. Szyszka, Ł. Tomczyk, V. Gulewska, D. Petrowski, Pedagogical University of Cracow, Kraków 2015, s. 93-106; M. Antunes, P. Marques, Transition to the Family Caregiver Role in Portugal, „Porto Biomedical Journal” 2017, nr 6, s. 6-11. 
Udział kolejnych grup wiekowych był odwrotnie proporcjonalny. Według prognoz liczba ludności w wieku 60 lat i więcej w Polsce wyniesie w $2030 \mathrm{r}$. $10,8 \mathrm{mln}$, a w 2050 r. $-13,7 \mathrm{mln}$. W 2050 r. grupa ta będzie stanowić ok. 40\% społeczeństwa ${ }^{31}$.

Bułgaria, położona na południowo-wschodnich peryferiach Europy, należała i nadal należy do najbiedniejszych państw na kontynencie pod względem większości wskaźników dobrobytu materialnego i społecznego ${ }^{32}$. Według statystyk populacja tego kraju w 2019 r. wynosiła 7,1 mln obywateli. „Bułgaria stoi w obliczu szybkiego starzenia się społeczeństwa. Obecnie wysokie tempo starzenia się ludności plasuje Bułgarię na 4. miejscu na świecie za Japonią, Włochami i Niemcami”33. Według stanu na 2018 r. ok. 28\% jej obywateli było w wieku 60 lat lub starszych, zaś do 2050 r. będzie miała $36,5 \%$ obywateli w wieku $60+{ }^{34}$.

Portugalia jest najstarszym państwem narodowym na Półwyspie Iberyjskim i jednym z najstarszych w Europie. „Badania demograficzne ujawniają rosnącą populację osób starszych w Portugalii w wyniku ogólnie zdrowszego społeczeństwa. Tej zwiększonej średniej długości życia towarzyszy jednak równoległy wzrost patologii degeneracyjnych i kosztów opieki wśród osób starszych"35. Pod koniec 2019 r. populacja tego państwa wynosiła 10,2 mln, z czego odsetek ludności starszej (60 lat i więcej) stanowił 27,9\%. Prognozy na 2050 r. wskazują na wzrost do $41,7 \%{ }^{36}$.

Uwarunkowania historyczno-polityczne, społeczne, gospodarcze czy kulturowe nadają starości demograficznej w Polsce, Bułgarii i Portugalii inne tempo i postać, wpływają też na społeczną percepcję seniorów czy na ich poglądy w różnych kwestiach. By poznać opinię polskich, bułgarskich i portugalskich seniorów na temat aktualnych trendów dotyczących starzenia się ludzkiego ciała i jego estetyzacji, przeprowadziłam badania, wykorzystując metodą ilościową (sondaż diagnostyczny), w okresie od września do grudnia 2019 r., będąc konsultantem w międzynarodowym projekcie Erasmus+ Adult Education, pt. Silver Civic Education (2017-1-PL01-KA204-038695). Uczestniczyli w nim seniorzy (w wieku 60+) - słuchacze Uniwersytetów Trzeciego Wieku (UTW),

31 Sytuacja osób starszych w Polsce w 2019 roku, Główny Urząd Statystyczny, Warszawa - Białystok 2021, https://stat.gov.pl/obszary-tematyczne/osoby-starsze, (dostęp: 7.10.2021)

32 Human Development Report 2016. Human Development for Everyone, United Nations Development Programme, New York 2016, http://hdr.undp.org/sites/default/files/2016_human_development_report.pdf (dostęp: 26.08.2020).

${ }_{33}$ N. Pitheckoff, Aging in the Republic of Bulgaria, „Gerontologist” 2017, t. 57, nr 5, s. 809.

34 World Population Ageing 2017, United Nations, Department of Economic and Social Affairs, Population Division, https://www.un.org/en/development/desa/population/publications/pdf/ageing/ WPA2017_Highlights.pdf (dostęp: 26.08.2021).

35 C. Oliveira, Research on Aging in Portugal, „Experimental Gerontology” 2001, t. 36, nr 10, s. 1599.

36 PORDATA, Statistics about Portugal's Population 2020, www.pordata.pt/en/Portugal (dostęp: 24.08.2021). 
funkcjonujących w Białymstoku, Sofii i Gondomar ${ }^{37}$. Respondenci dobrowolnie (świadoma zgoda) wzięli udział w badaniu. Ankiety rozdałam podczas prowadzonych przeze mnie warsztatów, realizowanych jako działanie projektowe. Część badanych wypełniła kwestionariusz w trakcie spotkania, inni - przynieśli go na kolejne. W sumie zebrałam 379 ankiet: Polska $(\mathrm{N}=123)$, Bułgaria $(\mathrm{N}=126)$ i Portugalia $(\mathrm{N}=130)$.

Ponad połowę $(58,8 \%)$ wszystkich respondentów stanowiły kobiety, których odsetek był najwyższy w próbie polskiej $(65,5 \%)$, natomiast najwyższy odsetek mężczyzn zaobserwowano w Portugalii (44,2\%). Wśród badanych przeważały osoby w wieku 60-69 lat (55,6\%) - seniorzy z Portugalii byli najliczniejsi w tej grupie (62,8\%). Wśród wszystkich respondentów 38,3\% było w wieku $70-79$ lat, a osoby w wieku 80 lat i więcej stanowiły 6,1\% (najrzadziej reprezentowane przez seniorów z Bułgarii: 2,4\%). Dane statystyczne wskazują, że 41,2\% respondentów posiadało wykształcenie średnie, $36,1 \%$ deklarowało wykształcenie wyższe, a pozostali $(22,7 \%)$ - podstawowe. Jeśli chodzi o specyfikę krajów partnerskich - wykształcenie wyższe najczęściej wskazywali respondenci z Bułgarii (51,6\%), a następnie z Polski (48,4\%). Osoby z Portugalii najczęściej wspominały o ukończeniu szkoły średniej (51,2\%).

Biorąc pod uwagę koncepcję estetyzacji życia codziennego, społeczeństwa i ciała, a także uwarunkowania społeczno-kulturowe charakterystyczne dla społeczeństwa polskiego, bułgarskiego i portugalskiego, w niniejszym artykule poszukuję odpowiedzi na następujące pytania: Jak osoby starsze postrzegają starzejące się ciało? Co sądzą o swoim starzejącym się ciele? Czy opinie badanych wskazują na dostrzeganie przez nich procesu estetyzacji starzejącego się ciała seniora? Czy respondenci internalizują społeczno-kulturowe oczekiwania wobec wyglądu starzejącego się ciała człowieka, czy też przeciwstawiają się im? Rozważenie tych pytań jest celem niniejszego tekstu. Przedstawione w artykule dane empiryczne mają charakter badań wstępnych, podjętych w celu rozpoznania problematyki społecznej percepcji starzejącego się ciała i jego estetyzacji.

\section{Piękno starzejącego się ciała seniora - mit czy prawda?}

Bohdan Dziemidok, snując rozważania nad temat aksjologicznych aspektów starości, tak pisze: „Nie będę spierał się o urodę starców, którzy rzeczywiście bardzo rzadko są piękni, nie mam natomiast najmniejszych wątpliwości, że chociaż nie można uzasadnić zbyt ogólnego stwierdzenia «starość jest piękna»,

37 Gondomar - gmina położona we wschodniej części portugalskiego obszaru metropolitalnego - Porto. 
to "starość może być piękna» jest twierdzeniem uzasadnionym"38. Starość, czyli etap życia przeżywany w zdrowiu, bliskości rodziny i poczuciu spełnienia faktycznie może być piękny. Jeśli jednak ciało niedomaga i rodzina jest daleko, trudniej dostrzec walory starości. Prezentację wyników badań rozpocznę zatem od wskazania, czym dla badanych jest starzejące się ciało człowieka, jak traktują własną cielesność i czy podzielają opinię B. Dziemidoka, iż starcy rzadko są piękni.

Wykres 1. Czym jest dla Pana/Pani starzejące się ciało seniora? (\%) $)^{39}$

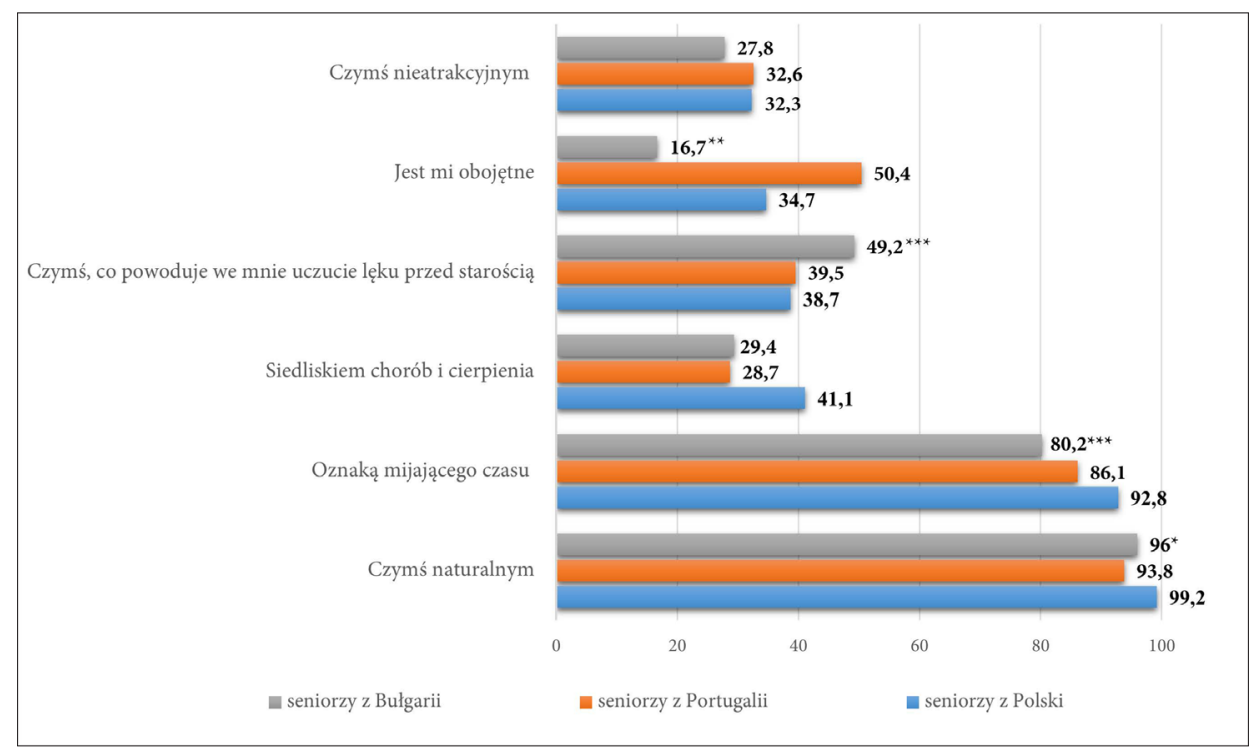

Źródło: opracowanie własne.

Analiza zgromadzonych danych wskazuje, że respondenci najczęściej ciało seniora pojmują jako coś naturalnego i normalnego - kraj ich pochodzenia nie różnicował wskazań w tym zakresie (wykres 1). Zwraca uwagę różnorodność opinii w odniesieniu do pozostałych odpowiedzi, tzn. dla 92,8\% respondentów z Polski starzejące się ciało człowieka jest oznaką mijającego czasu i to właśnie ta grupa badanych najczęściej $(24,2 \%)$ wskazywała, że własne ciało traktuje jako przedmiot troski i solidnej pracy (wykres 2).

38 B. Dziemidok, Aksjologiczne aspekty starości; czy starość może być piękna, dobra, mądra i szczęśliwa?, „ЕОФIA” 2014, nr 14, s. 159.

39 Wykres przedstawia odpowiedzi badanych na pytanie wielokrotnego wyboru. Przy korelacjach poszczególnych wskazań spełniających warunek istotności statystycznej, informację tę zamieściłam, przyjmując następujące oznaczenia: ${ }^{*} \mathrm{p}<0,05$; ${ }^{* *} \mathrm{p}<0,01$; ${ }^{* *} \mathrm{p}<0,001$. Brak wskazania poziomu istotności oznacza, iż dana korelacja nie była znamienna statystycznie. 
Wykres 2. Czym dla Pana/Pani, jest Pana/Pani własne ciało? (\%) ${ }^{40}$

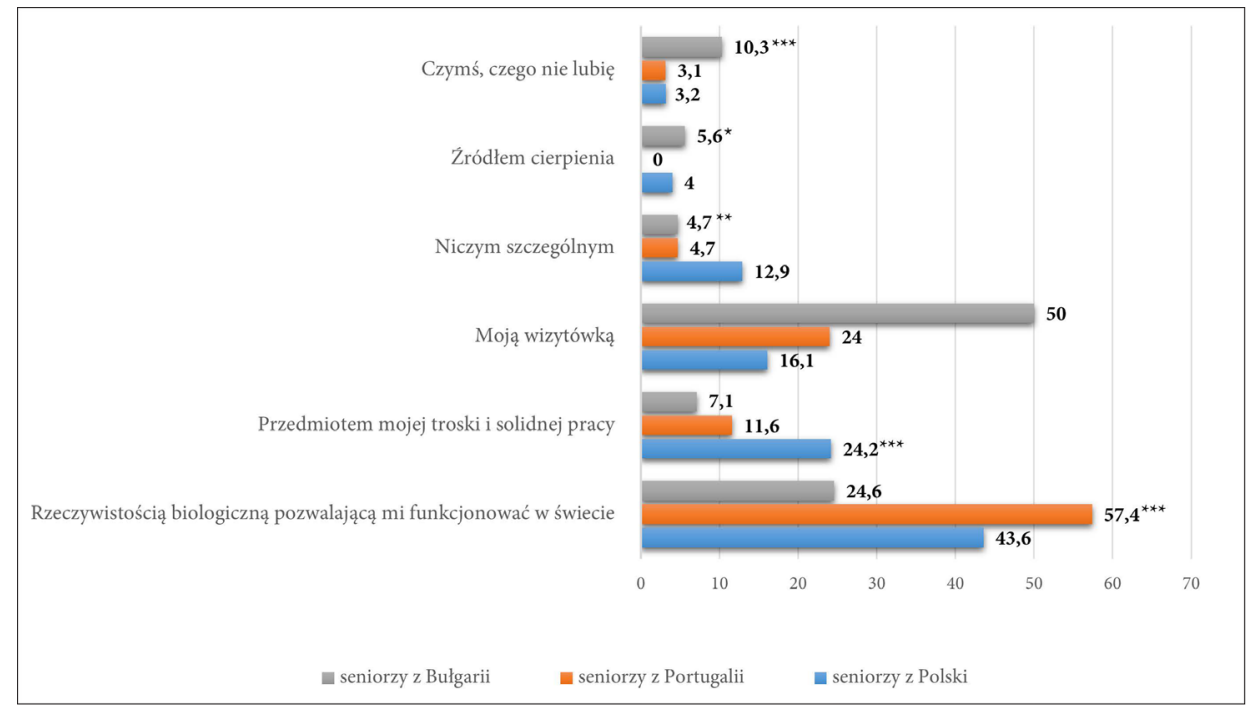

Źródło: opracowanie własne.

W innym miejscu zapytałam seniorów, czy uważają siebie za osoby dbające o własne ciało, i okazało się, że $75,8 \%$ badanych z Polski udzieliło odpowiedzi twierdzącej. Niewykluczone, że ankietowani mają świadomość zmian dokonujących się na skutek postępujących procesów starzenia się. Prawdopodobne jest też, że próbują im zaradzić, być może poprawiając/estetyzując swoje ciało. Piękno to wartość szczególnie bliska kobietom, a te stanowiły ponad połowę badanych.

Nieco inaczej odpowiadali respondenci z Portugalii. Połowa $(50,4 \%) \mathrm{z}$ nich wskazywała, że starzejące się ciało seniora jest im obojętne (wykres 1), zaś własną cielesność (wykres 2) pojmują jako rzeczywistość biologiczną pozwalającą im funkcjonować w świecie $(57,4 \%)$. Trzeba też dodać, że niemal wszyscy badani z tego kraju $(94,6 \%)$ uznali się za osoby dbające o własne ciało, co wyróżnia ich wśród wszystkich respondentów.

Z kolei odpowiedzi Bułgarów można zinterpretować jako dość niezdecydowane i być może świadczące o odczuwanym przez nich dyskomforcie wywołanym poruszaną tematyką. Otóż 49,2\% badanych seniorów z Sofii wskazało, że starzejące się ciało wywołuje w nich lęk przed starością, zaś 10,3\% z nich wskazało, iż nie lubi swego ciała. Co ciekawe, 47,6\% respondentów z Bułgarii

40 Wykres przedstawia odpowiedzi badanych na pytanie wielokrotnego wyboru - seniorzy mogli wskazać maksymalnie dwie. Przy korelacjach poszczególnych wskazań, spełniających warunek istotności statystycznej, informację tę zamieściłam, przyjmując następujące oznaczenia: ${ }^{*} \mathrm{p}<0,05 ;{ }^{* *} \mathrm{p}<0,01$; ${ }^{* *} \mathrm{p}<0,001$. Brak wskazania poziomu istotności oznacza, iż dana korelacja nie była znamienna statystycznie. 
uznało się za osoby dbające o własne ciało, 19,1\% wyraziło opinię przeciwną, zaś 1/3 miała problem z zajęciem stanowiska w tej sprawie, odpowiadając: „trudno powiedzieć”. Bez wątpienia kraj pochodzenia respondentów, związana z tym kultura czy warunki społeczno-gospodarcze różnicują ich stanowisko wobec analizowanych zagadnień. Widać to równie wyraźnie w odpowiedziach udzielanych przez respondentów na pytanie o wyznaczniki atrakcyjności/ piękna ciała osoby starszej (wykres 3).

Wykres 3. Jakie Pana/Pani zdaniem powinno być ciało seniora, by można było je nazwać ciałem atrakcyjnym? $(\%)^{41}$

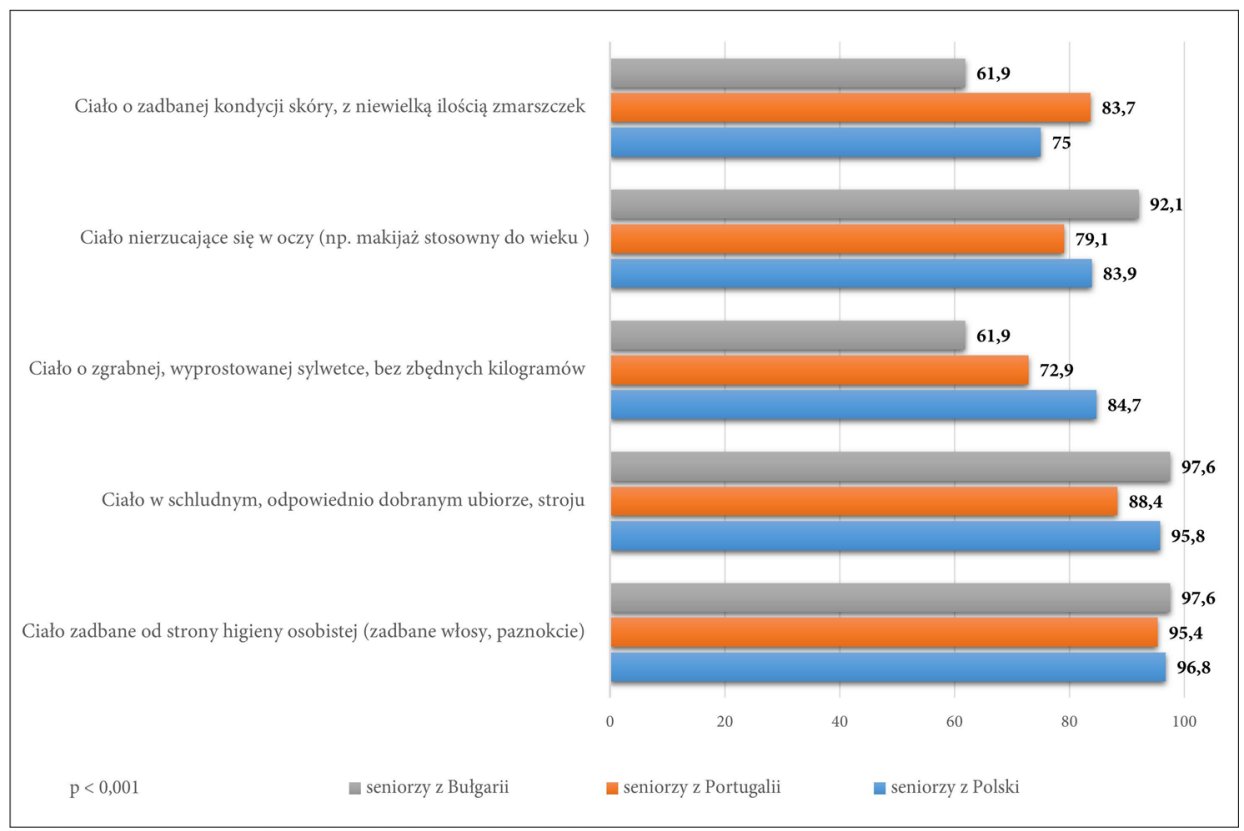

Źródło: opracowanie własne.

Wskazania seniorów sugerują, że powszechne przekonania na temat tego, co definiuje atrakcyjną fizyczność człowieka, postrzegają oni jako odnoszące się również do osób starszych. Wydaje się jednak, że zarówno wiek badanych, jak i kraj pochodzenia przyczyniają się do nadawania określonej rangi poszczególnym wyznacznikom.

${ }^{41}$ Wykres przestawia wyłącznie twierdzące odpowiedzi badanych (suma odpowiedzi zdecydowanie tak i raczej tak) na pytanie, w którym do testowania poszczególnych wskazań zastosowałam skalę Likerta. Korelacje wszystkich prezentowanych wskazań spełniają warunek istotności statystycznej, gdzie $\mathrm{p}<0,001$. 
Niemal wszyscy seniorzy zgodzili się co do tego, że atrakcyjne ciało jest zadbane od strony higieny osobistej (umyte włosy, czyste paznokcie itd.). Bułgarzy $(97,6 \%)$ i Polacy $(95,8 \%)$ częściej niż Portugalczycy $(88,4 \%)$ zwracali uwagę na schludny i dostosowany do wieku ubiór seniora. W przypadku pozostałych wskazań, kraj pochodzenia badanych znacząco różnicował ich odpowiedzi. Seniorów z Bułgarii wyróżniało zdecydowane (92,1\%) poparcie opinii mówiącej o tym, że atrakcyjne ciało seniora to takie, które nie rzuca się w oczy, np. kobiety nie powinny nosić krzykliwego makijażu czy koloru włosów. Polscy badani najczęściej $(84,7 \%)$ spośród wszystkich wskazywali na zgrabną sylwetkę, czyli sylwetkę bez zbędnych kilogramów, zaś Portugalczycy zdecydowanie częściej $(83,7 \%)$ niż pozostali uznawali, że zadbana kondycja skóry z niewielką ilością zmarszczek pozwala nazwać ciało osoby starszej atrakcyjnym. Skoro tak, czy zdaniem badanych starzejące się ciało współczesnego seniora jest atrakcyjne pod względem fizycznym (tabela 1)?

Tabela 1. Opinie badanych na temat fizycznej atrakcyjności współczesnego seniora

\begin{tabular}{|l|r|r|r|r|r|r|}
\hline $\begin{array}{c}\text { Czzy Pana/Pani zdaniem starzejące } \\
\text { się ciało współczesnego seniora } \\
\text { jest atrakcyjne pod względem } \\
\text { fizycznym? }\end{array}$ & \multicolumn{2}{|c|}{ Seniorzy z Polski } & \multicolumn{2}{c|}{$\begin{array}{c}\text { Seniorzy } \\
\text { z Portugalii }\end{array}$} & \multicolumn{2}{c|}{$\begin{array}{c}\text { Seniorzy } \\
\text { z Bułgarii }\end{array}$} \\
\cline { 2 - 7 } & $\mathrm{N}$ & $\%$ & $\mathrm{~N}$ & $\%$ & $\mathrm{~N}$ & $\%$ \\
\hline Zdecydowanie tak & 5 & 4,0 & 16 & 12,4 & 2 & 1,6 \\
\hline Raczej tak & 47 & 37,9 & 65 & 50,4 & 19 & 15,1 \\
\hline Raczej nie & 37 & 29,8 & 0 & 0,0 & 13 & 10,3 \\
\hline Zdecydowanie nie & 7 & 5,7 & 35 & 27,1 & 45 & 35,7 \\
\hline Trudno powiedzieć & 28 & 22,6 & 13 & 10,1 & 47 & 37,3 \\
\hline Razem & 124 & 100,0 & 129 & 100,0 & 126 & 100,0 \\
\hline
\end{tabular}

Źródło: opracowanie własne.

Najbardziej pozytywnie wypowiadali się Portugalczycy, wśród których 62,8\% udzieliło odpowiedzi twierdzącej, a 27,1\% - przeczącej. Polacy byli bardzo podzieleni, gdyż 41,9\% odpowiedziało „tak”, nieco mniej $(35,5 \%)$ zaznaczyło odpowiedź „nie”, a 22,6\% - „trudno powiedzieć”. Najbardziej krytyczny był głos Bułgarów, wśród których jedynie 16,7\% przyznało, że ciało współczesnego seniora jest atrakcyjne pod względem fizycznym, blisko połowa $(46,0 \%)$ odpowiedziała, że tak nie jest, a 37,3\% zaznaczyło odpowiedź „trudno powiedzieć”.

Na pierwszy rzut oka odpowiedzi badanych dotyczące wyznaczników piękna ciała w starości, jak też ich stosunek wobec tego stanu rzeczy, mogą zaskakiwać, bo nie są przychylne osobom starszym. Czyżby seniorzy podzielali opinię B. Dziemidoka, realnie oceniali rzeczywistość i mieli świadomość, że uroda i piękno ciała przemijają? Niewykluczone. Niemniej starość nie zwalania osób 
starszych z troski o swoją aparycję. Zapytałam osoby badane, czy ich zdaniem współcześni seniorzy dbają o wygląd zewnętrzny? Ogólnie rzecz biorąc, respondenci najczęściej odpowiadali "tak”, aczkolwiek zwraca uwagę stopień poparcia tejże opinii. Najczęściej $(88,4 \%)$ pozytywne stanowisko zajmowali mieszkańcy Portugalii. Z kolei seniorzy z Polski choć w przeważającej części $(62,1 \%)$ wyrażali się pozytywnie o dbaniu ich rówieśników o wygląd, to jednak $1 / 3 \mathrm{z}$ nich nie potrafiła zająć stanowiska w tej sprawie. Jeszcze bardziej zróżnicowane były opinie ankietowanych z Bułgarii, wśród których 54,0\% uznało, że dzisiejszy senior dba o wygląd zewnętrzny, ale $23,0 \%$ odpowiedziało, że tak nie jest, i dokładnie tyle samo zaznaczyło odpowiedź „trudno powiedzieć”.

W przedstawionych dotąd wynikach daje się zauważyć pozytywny stosunek portugalskich seniorów wobec analizowanych zagadnień. Z czego może wynikać?

W latach 1926-1974 w Portugalii panował reżim tzw. Nowego Państwa. António de Salazar nie był zainteresowany rozwojem stosunków z demokratyczną Europą, krzewił ideologię familializmu, w którą wpisywał się obraz uległej kobiety i dominującego mężczyzny. Inês Brasão opisując powojenną Portugalię, w której dokonywał się proces socjalizacji dzisiejszych seniorów, podkreśla, że „dostęp kobiet do życia publicznego, zwłaszcza mężatek, postrzegany był jako poważnie szkodzący życiu domowemu, nie tylko od strony materialnej, ale i moralnej. Ideał męskości wiązał się z kolei, z rolą obrońcy rodziny przed wszelkimi niebezpieczeństwami świata zewnętrznego" ${ }^{42}$. Być może interpretację wskazań portugalskich seniorów należy przeprowadzić w kontekście opisywanego przez I. Brasão systemu normatywnego czasów socjalizacji portugalskich seniorów oraz zmiennej, jaką jest ich płeć. Przypomnę, że 44,2\% respondentów z Portugalii stanowili mężczyźni, co w badaniach wśród seniorów bardzo rzadko się zdarza, m.in. ze względu na feminizację starości. Płeć jest znaczącym determinantem postaw kobiet i mężczyzn wobec ciała człowieka. Mężczyźni z większym dystansem podchodzą do następstw procesu starzenia się, w tym także tych związanych $\mathrm{z}$ wyglądem fizycznym ${ }^{43}$. Nie można też wykluczyć, że dla portugalskich seniorek ważniejsze niż troska o atrakcyjność fizyczną są inne wartości, głównie te związane z rodziną. Badania wskazują ponadto, że im kobiety są starsze, tym większe znaczenie w kształtowaniu pozytywnego spojrzenia na własne ciało mają dla nich

${ }^{42}$ I. Brasão, Gender and Consumer Behaviour: A Portrait of Portugal in the 1960s, w: Consumption and Gender in Southern Europe Since the Long 1960s, red. K. Kornetis, E. Kotsovili, N. Papadogiannis, Bloomsbury Academic London 2016, s. 86.

43 E. Schwaiger, Performing Youth. Ageing, Ambiguity and Bodily Integrity, „Social Identities” 2009, t. 15, nr 2, s. 273-284; U. Kluczyńska, Redefiniowanie męskości. Kulturowo-społeczne konteksty starzenia się mężczyzn, w: Pomyślne starzenie się w perspektywie nauk społecznych i humanistycznych, red. J. T. Kowaleski, P. Szukalski, Wydawnictwo UŁ, Łódź 2009, s. 76-88. 
poczucie osobistej skuteczności w działaniu, wiara we własne umiejętności, dobry nastrój oraz pozytywne relacje $\mathrm{z}$ innymi ludźmi ${ }^{44}$.

Zupełnie przeciwnie do wskazań Portugalczyków odpowiadali Bułgarzy. Powojenna Bułgaria, podobnie jak Polska, była krajem komunistycznym aż do 1989 r. Natalie Pitheckoff opisując dokonujące się zmiany, m.in. w kontekście procesu starzenia się społeczeństwa Bułgarii, wskazuje, że kształtujący się system demokratyczny otworzył nowe perspektywy. Podkreśla m.in. rosnącą świadomość społeczną w zakresie licznych wyzwań, jakie pociąga za sobą starość demograficzna, sygnalizując też, jak wiele jest jeszcze do zrobienia. Oprócz kluczowych spraw, jak np. zapewnienie opieki i wsparcia osobom starszym, zadbanie o godną wysokość emerytur, ważne jest przeciwdziałanie panoszącemu się ageizmowi i negatywnym stereotypom dotyczącym osób starszych. Starsi dorośli są nierzadko postrzegani jako ciężar dla społeczeństwa ${ }^{45}$. Nie można wykluczyć, iż krytyczne opinie badanych seniorów z Sofii mają swoje zakorzenienie $\mathrm{w}$ panujących $\mathrm{w}$ Bułgarii stereotypowych przekonaniach dotyczących starości i ludzi starszych. Co więcej, Boyko Borissov, komentując dokonującą się w Bułgarii transformację, zwraca uwagę na doświadczane przez Bułgarów trudności w przejmowaniu odpowiedzialności za własne życie i rozwój. „Państwo totalitarne przejęło odpowiedzialność za rozwój osobisty i publiczny. Największym wyzwaniem dla narodu był fakt, że stracił on z oczu potrzebę rozwoju osobistego i publicznego. Duża liczba Bułgarów pragnęła zmian zewnętrznych, ale protestowała przeciwko przekonaniu, że oni również muszą się zmienic" "46. Spostrzeżenia te wydają się być szczególnie trafne w odniesieniu do osób starszych, które swoją młodość i dorosłe życie przeżyły w warunkach dawnego systemu. Tworzyły one ówczesną rzeczywistość, więc nic dziwnego, że zanik stabilności i bezpieczeństwa zapewnianych przez uczestnictwo w bloku komunistycznym spowodował dezorientację, żeby nie powiedzieć - niezadowolenie ludności. Naturalne jest dążenie człowieka do poczucia „ciągłości” swojej biografii. Publiczna krytyka „uwikłania” w poprzedni system w pewien sposób uderza w seniorów. Niemniej blisko 30-letnie wysiłki na rzecz budowania społeczeństwa demokratycznego zdają się przynosić zakładane rezultaty, tzn. Bułgarzy chcą lepszego życia i są gotowi podejmować wysiłki w tym zakresie ${ }^{47}$.

44 M. Kochan-Wójcik, J. Piskorz, Zmiany w zakresie postrzegania i oceny własnego ciała wśród kobiet od okresu dojrzewania do dorosłości, „Psychologia Rozwojowa” 2010, t. 15, nr 3, s. 21-32; C. Gilleard, P. Higgs, M. Hyde, R.D. Wiggins, D.B. Blane, Class, Cohort, and Consumption. The British Experience of the Third Age, "Journals of Gerontology Series B: Psychological Sciences and Social Sciences" 2005, t. 60, nr 6, s. 305-310.

45 N. Pitheckoff, Aging in the Republic of Bulgaria..., s. 813.

46 B. Borissov, The Bulgarian Transition Towards Democracy and the Challenges of the New Perspective, „European View” 2008, t. 7, nr 1, s. 46.

47 Tamże, s. 51. 
Prawdopodobnie praktyki te są również udziałem części bułgarskich seniorów, którzy - w porównaniu do pozostałych badanych grup - byli najlepiej wykształceni, tzn. 51,6\% deklarowało posiadanie wyższego wykształcenia.

Trzecią badaną grupą byli seniorzy z Polski, zajmujący wobec analizowanych kwestii - jak się wydaje - postawę, którą można umiejscowić pomiędzy tą wyrażaną przez Portugalczyków i Bułgarów. Na czym polega polska specyfika?

Trzydziesta rocznica wydarzeń z czerwca ' 89 sprzyjała prowadzeniu licznych sondaży na temat stosunku Polaków do zmian zapoczątkowanych transformacją ustrojową. Badania wskazują, że najczęściej (47,0\%) pozytywną ocenę następstw wydarzeń ' 89 przejawiały osoby w wieku 56-70 lat, zaś najstarsi badani (powyżej 70. roku życia) byli najbardziej ze wszystkich grup wiekowych ambiwalentnie nastawieni do wydarzeń sprzed 30 lat $^{48}$. Zdaniem Barbary Szatur-Jaworskiej niejednorodne warunki, jakie pokoleniu wyżu demograficznego stwarzała polityka społeczna, sprawiają, że tylko niewielka część seniorów może korzystać $\mathrm{z}$ waloryzowanej starości ${ }^{49}$. Do tego grona należą najmłodsi seniorzy. Z badań wynika, że to właśnie oni, częściej niż pozostali, nie uważają się za bezradnych i nieporadnych, a 55\% osób w wieku 60-64 lat twierdzi, że nie ma takich spraw, w których oczekiwałyby pomocy. Pozostali ankietowani potrzebowaliby wsparcia głównie w przypadku kontaktów z lekarzem lub wizyt w urzędzie. Badania wskazują też, że niemal co czwarta ankietowana osoba starsza szuka dla siebie nowej roli w życiu. Część seniorów chce pozostać wartościowymi członkami społeczeństwa, dlatego dąży do zachowania sprawności - zarówno fizycznej, jak i umysłowej, przyjmując aktywną postawę wobec życia i otaczającej rzeczywistości ${ }^{50}$. Może być to następstwem upowszechniania się w Polsce juwenalizacji kultury, mającej wiele wspólnego z estetyzacją starzejącego się ciała. Dotychczasowe rozpoznanie tematu wiedzie do wniosku, iż młodsi seniorzy, czyli osoby w wieku 60-64 lata, których wśród polskich emerytów jest 28,4\%, zdecydowanie częściej niż osoby w wieku 80-90 lat i więcej, pozytywnie opiniują różne zachowania rówieśników, poprzez które chcą oni poprawić wygląd ciała. Prawdopodobnie wynika to z nieco lepszej kondycji zdrowotnej tychże młodszych seniorów, jak też z faktu przeżywania przez nich połowy swego dorosłego życia w warunkach Polski potransformacyjnej, zupełnie innej niż Polska czasów PRL.

Mając w pamięci omówione wyżej wskazania badanych seniorów, wracam do pytania postawionego w śródtytule powyższego fragmentu tekstu. Piękno starzejącego się ciała seniora - mit czy prawda? Jednoznaczna odpowiedź nie

48 A. Głowacki, Trzydziesta Rocznica obrad Okragłego Stołu, Raport CBOS, Warszawa 2019, https://www.cbos.pl/SPISKOM.POL/2019/ K_016_19.PDF (dostęp: 7.10.2021).

49 B. Szatur-Jaworska, Polska polityka społeczna wobec starzenia się ludności w latach 1971-2013, Dom Wydawniczy Elipsa, Warszawa 2016, s. 482.

50 A. Kaniewska-Sęba, Polscy seniorzy - wyzwanie dla marketingu w XXI wieku, „Środkowoeuropejskie Studia Polityczne" 2016, nr 4, s. 145-158. 
jest możliwa. I mimo że spośród trzech badanych grup jedynie głos Bułgarów był znacząco krytyczny, wydaje się, iż niezdecydowanie Polaków bardziej skłania do puenty: mit. Cytowany wyżej B. Dziemidok pisząc o wątpliwej urodzie starców, był już w wieku sędziwym (miał 80 lat). Wydaje się, że mógł wyrażać opinię swoich rówieśników.

\section{Estetyzacja starzejącego się ciała seniora - mit czy prawda?}

Estetyzacja zdaje się być globalnym trendem obejmującym zarówno sposób widzenia oraz rozumienia otaczającej nas rzeczywistości społeczno-kulturowej, jak i techniki kształtowania ciała i osobowości. Dążenie do tego, by świat uczynić pięknym, obok pozytywnych następstw może mieć te niekorzystane. Nadawanie wszystkiemu ładnego wyglądu może zrodzić obojętność wobec piękna albo może mieć negatywny wpływ na jeden z kluczowych podmiotów biorących udział w procesach estetyzacji, jakim jest człowiek. „Z jednej strony człowiek jest czynnikiem porządkującym świat dany mu w spostrzeżeniu (...). $\mathrm{Z}$ drugiej zaś, jest zdolny uświadomić sobie, że podlega spojrzeniu drugiego człowieka, stając się elementem estetyzacji”" ${ }^{\prime \prime}$. Inni mogą postrzegać nas jako osoby atrakcyjne lub przeciwnie - jako uosobienie destrukcji, ze względu na niedopasowanie do obowiązujących kanonów. Dezaprobata otoczenia może rodzić w człowieku potrzebę zniknięcia z pola widzenia albo zabiegania o zaistnienie w świecie innych ludzi. W jakim stopniu tendencjom tym ulegają badani seniorzy? Czy dostrzegają przejawy estetyzacji starzejącego się ciała ich rówieśników? Co sądzą o tego typu praktykach?

Odpowiedzi badanych zebrane na wykresie 4 mogą sugerować, że estetyzacja starzejącego się ciała może być „dziejącym się” procesem. Uwagę zwraca prawdopodobny inny stopień jego przebiegu w poszczególnych krajach.

Pisałam wyżej, że wyznacznikiem atrakcyjnego ciała seniora dla badanych Polaków jest m.in. schludny, odpowiednio dobrany strój. Opinię tychże respondentów warto powiązać z ich stanowczym przekonaniem, że dzisiejsze kobiety $(81,5 \%)$ i mężczyźni $(68,6 \%)$ w starszym wieku ubierają się lepiej, bardziej kolorowo czy odmładzająco w porównaniu do swoich rówieśników sprzed 30 lat (wykres 4). Wydaje się, że odpowiednie zadbanie o opakowanie ciała, czyli ubiór, może być jedną z prostszych strategii upiększenia jego wyglądu. Powinno się to jednak dokonywać w granicach rozsądku, gdyż jak zauważają badani, szczególnie ci z Bułgarii $(84,1 \%)$, wśród współczesnych starszych kobiet wiele jest takich, które chcą się przesadnie odmłodzić, np. wybierając strój czy makijaż nieodpowiedni do wieku. Ponadto seniorzy z Polski $(88,7 \%)$

\footnotetext{
51 M. Gołaszewska, Estetyka rzeczywistości..., s. 165.
} 
Wykres 4. Opinie badanych na temat przejawów estetyzacji starzejącego się ciała seniora $(\%)^{52}$

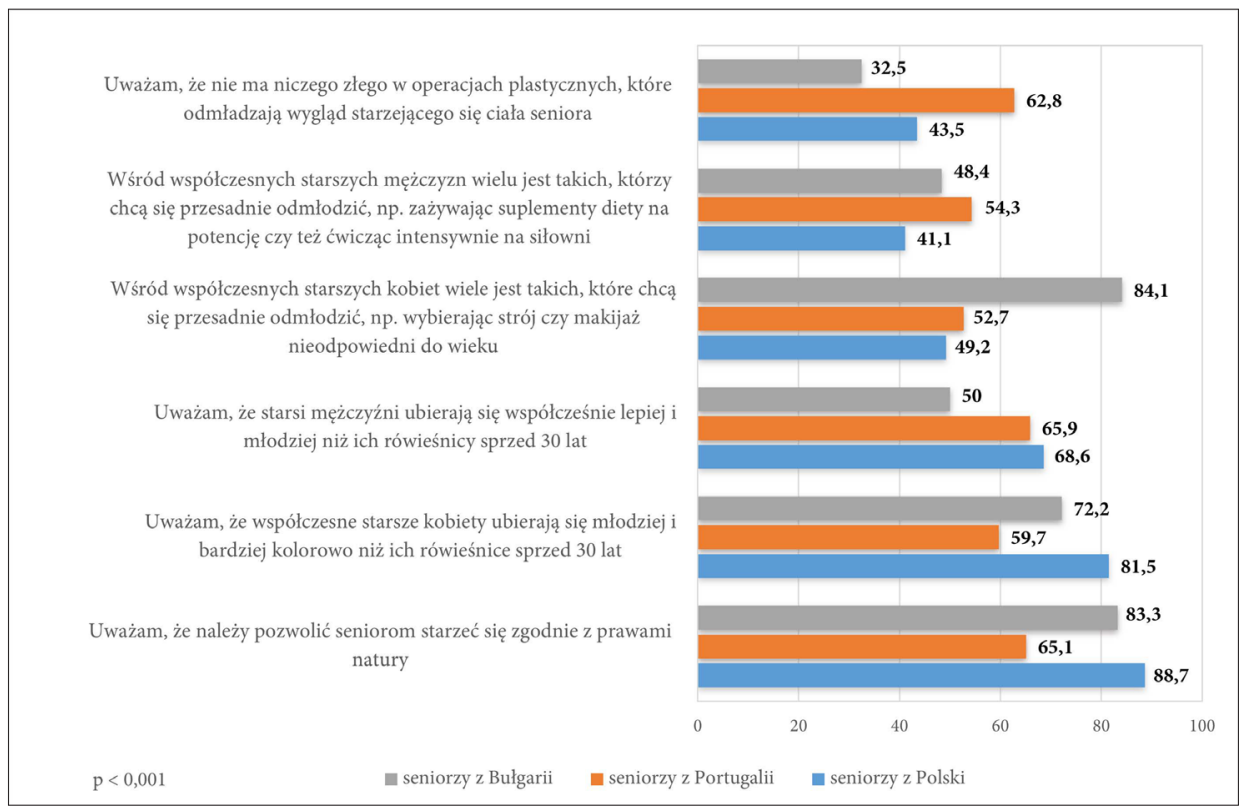

Źródło: opracowanie własne.

i Bułgarii (83,3\%) częściej niż Portugalczycy $(65,1 \%)$ wyrażali opinię, iż osobom starszym należy pozwolić starzeć się zgodnie z prawami natury, czyli przesadnie ich nie odmładzać. Z kolei seniorzy z Portugalii najczęściej ze wszystkich pozytywnie opiniowali poszczególne kwestie związane z zagadnieniem estetyzacji starzejącego się ciała. Zgadzają się nawet $(62,8 \%)$ na operacje plastyczne, odmładzające wygląd seniora, o czym dowiadujemy się z danych zebranych na wykresie 4. Portugalczycy często wskazywali, że dbają o własne ciało i to dla nich atrakcyjność starzejącego się ciała wyznaczała m.in. twarz z niewielką ilością zmarszczek. Nic więc dziwnego, że popierają operacje plastyczne.

Simone de Beauvoir pisze: „nigdy nie mówi się o «pięknej staruszce», w najlepszym wypadku można spotkać sformułowanie «urocza starsza pani». Tymczasem niektórzy «piękni starcy» budzą zachwyt. Rodzaj męski nie pada łupem starości. Nikt nie wymaga od niego ani świeżości, ani słodyczy czy wdzięku, lecz siły i inteligencji zdobywcy"s3. Cytat ten pomaga zrozumieć opinie ankietowanych mężczyzn, dla których starość zdaje się być łaskawsza - najwięcej

${ }^{52}$ Wykres przestawia wyłącznie twierdzące odpowiedzi badanych (suma odpowiedzi zdecydowanie tak i raczej tak) na pytanie, w którym do testowania poszczególnych wskazań zastosowałam skalę Likerta. Korelacje wszystkich prezentowanych wskazań spełniają warunek istotności statystycznej, gdzie $\mathrm{p}<0,001$.

53 S. de Beauvoir, Starość, tłum. Z. Styszyńska, Wydawnictwo Czarna Owca, Warszawa 2011, s. 335. 
było ich w Portugalii. Wśród badanych z Polski i Bułgarii dominowały kobiety, prawdopodobnie bardziej świadome procesów estetyzacji ciała, wydaje się też, że bardziej wobec takich praktyk krytyczne i niegodzące się na sprowadzenie cielesności w starości wyłącznie do wyglądu. Warto też przypomnieć, że badani z Półwyspu Iberyjskiego, którzy ok. 15 lat wcześniej niż Polacy czy Bułgarzy doświadczyli dobrodziejstw powrotu do systemu demokratycznego, po Rewolucji Goździków z 1974 r., wcześniej mogli już poznać i przyjąć wzorce kultury Europy Zachodniej i w związku z tym mogą traktować je albo jako „oczywistą oczywistość", albo „już" nie zachwycają się nimi, albo - w przeciwieństwie do reszty badanych - zajmują wobec nich postawę akceptacji. Chcąc zatem odpowiedzieć na pytanie sformułowane w śródtytule tej części tekstu, prawdopodobna jest puenta: estetyzacja starzejącego się ciała seniora, w opinii badanych, jest prawdą. Proces ten faktycznie "dzieje się".

\section{Podsumowanie}

Stara jak świat prawda niezmiennie przypomina: $\mathrm{z}$ upływem lat nasz wygląd zmienia się. Zdaniem M. Gołaszewskiej: „podejmujemy niekiedy bezsilne bunty, próby ratowania swojego wyglądu jako młodych (jeszcze młodych, potem już tylko "wyglądających młodo»), a wreszcie musimy zaakceptować siebie w roli starszych, starzejących się. Czy istotnie człowiek akceptuje siebie jako starego? Ta cała komedia chwytania się pozostających w nas jeszcze okruchów młodości przybiera u niektórych ludzi charakter wręcz obsesyjny, a wynika ze ślepego kultu młodości. Tymczasem wiadomo, że młodość nie jest kategorią wyłącznie biologiczną. Możemy czuć się i być młodzi psychicznie, niezależnie od wieku biologicznego" ${ }^{24}$. Trudno jednak zaprzeczyć, iż starość to etap życia, w którym fizjologiczny (cielesny), psychologiczny i społeczny wymiar warunkują się wzajemnie. Omówione w tej pracy opinie osób starszych zdają się potwierdzać tę tezę.

Mając w pamięci wskazania badanych seniorów z Polski, Bułgarii i Portugalii, można by powiedzieć tak: starzeć się pięknie, to starzeć się z ciałem sprawnym, nieotyłym, zadbanym od strony higieny osobistej i odpowiednio ubranym. Starzeć się pięknie można również wtedy, gdy inni nie wymagają, by senior czy seniorka „siłował(a) się" z prawami natury, gdy dają im prawo do korzystania z nowinek modowych i tolerują bardziej kolorowe opakowanie ich ciała (ubiór), a nawet poddawanie się operacjom plastycznym. Można też przyjąć hipotezę, którą chciałabym zweryfikować, prowadząc badania jakościowe, iż badani seniorzy dostrzegają przejawy estetyzacji starzejącego się ciała seniora, a kraj ich pochodzenia różnicował stopień internalizacji społeczno-kulturowych

54 M. Gołaszewska, Estetyka rzeczywistości..., s. 166. 
oczekiwań wobec wyglądu starzejącego się ciała człowieka. Estetyzacja własnego ciała wykracza poza naszą sylwetkę, twarz, mimikę, ruchy - wchodzi w głąb człowieka i w jego sposoby autoidentyfikacji. Duże znaczenie odgrywa w tym zakresie środowisko zewnętrzne, a zwłaszcza kultura i uwarunkowania społeczno-gospodarcze.

I choć seniorzy nie są homogeniczną grupą, a ich postawa wobec różnych problemów uwarunkowana jest stanem ich zdrowia, sytuacją ekonomiczną, poziomem wykształcenia itp., jest mało prawdopodobne, że uda im się oprzeć wpływom juwenalizacji kultury i procesu estetyzacji ciała. Na naszych oczach kształtuje się też nowa generacja seniorów, którzy prawdopodobnie doskonale odnajdą się w tej estetycznej rzeczywistości. Nazywamy ich Młodzi-Starzy (Young-Old) lub Yold. Rok 2020 jest początkiem dekady Yold. Są to ludzie w wieku 65-75 lat, urodzeni w okresie powojennego wyżu demograficznego, głównie w latach 1955-1960. Cenią indywidualizację, autoekspresję, optymizm, „tu i teraz”. Są zdrowsi i zamożniejsi niż poprzednie pokolenia seniorów. Podważają tradycyjne oczekiwania wobec emerytów jako ludzi noszących kapcie i opiekujących się wnukami. Lubią wygodę i korzystają z internetu, zwłaszcza w celu uzyskania informacji na temat zdrowia lub jako środka komunikacji z innymi (korzystają z portali społecznościowych) ${ }^{55}$. Młodzi-starzy mogą zmienić świat i stereotypowy (pejoratywny) sposób postrzegania seniorów. Jednak potrzebują do tego zaangażowanej i przychylnej im postawy reszty społeczeństwa.

\section{Bibliografia}

Antunes P, Marques P., Transition to the Family Caregiver Role in Portugal , ,Porto Biomedical Journal" 2017, t. 2, nr 6, s. 6-11.

Bargłowski K., Where, What and Whom to Study? Principles, Guidelines and Empirical Examples of Case Selection and Sampling in Research, w: Qualitative Research in European Migration Studies, red. R. Zapata-Barrero, E. Yalaz, Springer, Cham 2018, s. 151-168.

Brasão I., Gender and Consumer Behaviour: A Portrait of Portugal in the 1960s, w: Consumption and Gender in Southern Europe Since the Long 1960s, red. K. Kornetis, E. Kotsovili, N. Papadogiannis, Bloomsbury Academic, London 2016, s. 85-102.

Borissov B., The Bulgarian Transition Towards Democracy and the Challenges of the New Perspective, „European View" 2008, t. 7, nr 1, s. 45-51.

Bourdieu P., Męska dominacja, tłum. L. Kopciewicz, Oficyna Naukowa, Warszawa 2004.

Brady E., Aesthetic Value, Ethics and Climate Change „Environmental Values”, 2014, t. 23, nr 5, s. 551-570.

Elzenberg H., Pisma estetyczne, oprac. i wstęp L. Hostyński, Wydawnictwo Uniwersytetu Marii Curie-Skłodowskiej, Lublin 1999.

Elias N., Przemiany obyczajów w cywilizacji Zachodu, tłum. T. Zabłudowski, PIW, Warszawa 1980. Flis M., Dynamika ciała w kulturze wizerunku, „Horyzonty Wychowania” 2008, t. 7, nr 14, s. 99-114.

55 J. Parker, The Decade of the Yold. „The Economist” 2020, https://worldin.economist.com/ article/17316/edition2020decade-young-old-begins (dostęp: 20.08.2020). 
Foucault M., Body/ Power, w: Michel Foucault. Power/Knowledge. Selected Interviews and Other Writings 1972-1977, red. C. Gordon, Harvester Press, Brighton 1980, s. 55-62.

Gilleard C., Higgs P., Hyde M., Wiggins R.D., Blane D.B., Class, Cohort, and Consumption. The British Experience of the Third Age, "Journals of Gerontology. Series B: Psychological Sciences and Social Sciences" 2005, t. 60, nr 6, s. 305-310.

Głowacki A., Trzydziesta Rocznica obrad Okragłego Stołu, Raport CBOS, Warszawa 2019, https:// www.cbos.pl/SPISKOM.POL/2019/ K_016_19.PDF (dostęp: 7.10.2021).

Gołaszewska M., Estetyka rzeczywistości, Instytut Wydawniczy PAX, Warszawa 1984.

Human development report 2016. Human development for everyone, United Nations Development Programme, New York 2016, http://hdr.undp.org/sites/default/files/2016_human_development_ report.pdf (dostęp: 26.08.2020).

Główny Urząd Statystyczny, Sytuacja osób starszych w Polsce w 2019 roku, Waszawa-Białystok 2021, https://stat.gov.pl/obszary-tematyczne/osoby-starsze (dostęp: 07.10.2021).

Ingarden R., Wykłady i dyskusje z estetyki, wybór i oprac. A. Szczepańska, wstęp W. Stróżewski, PWN, Warszawa 1981.

Jakubowska H., Socjologia ciała, Wydawnictwo Naukowe Uniwersytetu im. A. Mickiewicza, Poznań 2009.

Jęczeń A., Estetyzacja w kulturze współczesnej jako poszukiwanie sensu, „Kultura - Media - Teologia" 2012, nr 8, s. 8-18.

Jimenez M., Etyka i estetyka w XXI wieku, tłum. E.I. Nowak, "Sztuka i Filozofia” 2012, t. 41, s. 15-23.

Kaniewska-Sęba A., Polscy seniorzy - wyzwanie dla marketingu w XXI wieku ,,'Środkowoeuropejskie Studia Polityczne" 2016, nr 4, s. 145-158.

Kaśkiewicz K., Michalski R., Estetyzacja moralności - dylematy współczesnego człowieka, w: Między etykq a estetyką. Rozważania nad problemem estetyzacji, red. K. Kaśkiewicz, R. Michalski, T. Siwiec, Wydawnictwo Naukowe UMK, Toruń 2017, s. 7-26.

Kersten A., When Craving Goodness Becomes Bad. A Critical Conception of Ethics And Aesthetics in Organizations, "Culture and Organization" 2008, t. 14, nr 2, s. 187-202.

Kluczyńska U., Redefiniowanie męskości. Kulturowo-społeczne konteksty starzenia się mężczyzn, w: Pomyślne starzenie się w perspektywie nauk społecznych i humanistycznych, red. J.T. Kowaleski, P. Szukalski, Wydawnictwo UŁ, Łódź 2008, s. 76-88.

Kochan-Wójcik M., Piskorz J., Zmiany w zakresie postrzegania i oceny własnego ciała wśród kobiet od okresu dojrzewania do dorosłości, „Psychologia Rozwojowa” 2010, t. 15, nr 3, s. $21-32$.

Konieczna-Woźniak R., „Odmłodzona starość” - implikacje podmiotowe i społeczne, „Studia Edukacyjne" 2012, nr 21, s. 249-262.

Kösser U., Piękne, dobre i prawdziwe? O estetyzacji i anestetyzacji historii, w: Między etykq a estetyka. Rozważania nad problemem estetyzacji, red. K. Kaśkiewicz, R. Michalski, T. Siwiec, Wydawnictwo Naukowe UMK, Toruń 2017, s. 261-295.

Mann T., Old Cells, Aging Bodies, and New Money. Scientific Solutions to the Problem of Old Age in the United States, 1945-1955, „Journal of World History” 2014, t. 24, nr 4, s. 797-822.

Mauss M., Socjologia i antropologia, tłum. M. Król, K. Pomian, J. Szacki, Wydawnictwo KR, Warszawa 2001.

Naukkarinen O., Everyday Aesthetic Practices, Ethics and Tact, „Aisthesis" 2014, t. 7, nr 1, s. 23-44.

Naoumova S., Ethnicity and Expectations Concerning Family Law and Family Values in Bulgaria, w: Family Law and Family Values, red. M. Mavis, Hart Publishing, London 2003, s. 277-294.

Oliveira C., Research on aging in Portugal, „Experimental Gerontology" 2001, t. 36, nr 10, s. 1599-1607. Ossowski S., U podstaw estetyki, PWN, Warszawa 1966.

Parker J., The decade of the yold, "The Economist"2020, https://worldin.economist.com/article/17316/ edition2020decade-young-old-begins (dostęp: 20.08.2020).

Pitheckoff N., Aging in the Republic of Bulgaria, "Gerontologist" 2017, t. 57, nr 5, s. 809-815.

PORDATA, Statistics about Portugal's Population 2020, www.pordata.pt/en/Portugal (dostęp: 24.08.2021). 
Reckwitz A., Odkrycie kreatywności. O procesie społecznej estetyzacji, łłum. K. Kończal, Z. Sucharska, Narodowe Centrum Kultury, Warszawa 2017.

Rychłowska-Niesporek A., Transformation of Family in Poland, w: Modern Social and Educational Challenges and Phenomena. Polish and Macedonian Perspectives, red. M. Szyszka, Ł. Tomczyk, V. Gulevska, D. Petrowski, Pedagogical University of Cracow, Cracow 2015, s. 93-106.

Schwaiger E., Performing Youth. Ageing, Ambiguity and Bodily Integrity, ,"Social Identitie" 2009, t. 15, nr 2, s. 273-284.

Shilling Ch., Socjologia ciała, tłum. M. Skowrońska, Wydawnictwo Naukowe PWN, Warszawa 2010. Szatur-Jaworska B., Polska polityka społeczna wobec starzenia się ludności w latach 1971-2013, Dom Wydawniczy Elipsa, Warszawa 2016.

Szuman S., O sztuce i wychowaniu estetycznym, Państwowe Zakłady Wydawnictw Szkolnych, Warszawa 1969.

Tatarkiewicz W., Dzieje sześciu pojęć: sztuka, piękno, forma, twórczość, odtwórczość, przeżycie estetyczne, PWN, Warszawa 1982.

Turner B., The Body and Society, Basil Blackwell, Oxford-New York 1984.

Twigg J., Fashion and Age. Dress, the Body and Later Life, Bloomsbury, London 2013.

Welsch W., Estetyka poza estetyką. O nowa postać estetyki, red. K. Wilkoszewska, tłum. K. Guczalska, Towarzystwo Autorów i Wydawców Prac Naukowych Universitas, Kraków 2005.

Welsch W., Est/etyka. Etyczne implikacje i następstwa estetyki, tłum. i oprac. D. Kolasa, T. Siwiec, w: Między etykq a estetyką. Rozważania nad problemem estetyzacji, red. K. Kaśkiewicz, R. Michalski, T. Siwiec, Wydawnictwo Naukowe UMK, Toruń 2017, s. 27-54.

World Population Ageing 2017, United Nations, Department of Economic and Social Affairs, Population Division, New York 2017, https://www.un.org/en/development/desa/population/ publications/pdf/ageing/WPA2017_Highlights.pdf (dostęp: 26.08.2021).

\section{Streszczenie}

Estetyzacja to proces, w którym coś „nieestetycznego” czyni się lub rozumie jako estetyczne. Ów globalny trend można dostrzec $\mathrm{w}$ różnych obszarach życia, $\mathrm{w}$ tym również w odniesieniu do ciała człowieka. W obliczu postępującego procesu starzenia się społeczeństwa warto zapytać, jak należy rozumieć proces estetyzacji starzejącego się ciała seniora? Niniejszy artykuł jest omówieniem opinii seniorów na temat estetyzacji starzejącego się ciała osoby starszej. Podstawą tekstu są badania ilościowe, przeprowadzone wśród osób w wieku 60 lat i więcej, pochodzących z Polski, Bułgarii i Portugalii. Wyniki badań wskazują, że kraj pochodzenia seniorów różnicuje ich postrzeganie starzejącego się ciała ludzkiego, jak i opinie na temat przejawów jego estetyzacji w starości. Najbardziej pozytywne opinie na temat analizowanych zjawisk wyrażali seniorzy z Portugalii, najbardziej krytyczni byli respondenci z Bułgarii, natomiast osoby z Polski przyjęły postawę pośrednią.

Słowa kluczowe: estetyzacja, osoby starsze, starzejące się ciało, badania porównawcze

\section{What Does It Mean to Grow Old Beautifully? Selected Remarks on the Aestheticization of the Ageing Body of Seniors}

\section{Summary}

Aestheticization is a process in which something "non-aesthetic" is made or is made to be understood as something aesthetic. This global trend is on the increase, and now it also covers human body. The indisputably advancing ageing processes in contemporary societies provoke a question how to under- 
stand the process of aestheticization of an aging human body? The paper offers a survey of opinions expressed by the researched elderly - aged 60 and over - concerning the process of aestheticization of the aging human body. The comparative, quantitative research was held in Poland, Bulgaria and Portugal. The research results show that the national background of the subjects strongly affects their opinions on the issues under study. The elderly from Portugal expressed the most positive view of the of corporeal aestheticization, while the Bulgarian seniors assessed these issues in the most critical fashion. The Polish group represented a middle position.

Key words: aestheticization; elderly people, ageing body, comparative study 
